\title{
Dead Spot Severity, Pseudothecia Development, and Overwintering of Ophiosphaerella agrostis in Creeping Bentgrass
}

\author{
John E. Kaminski and Peter H. Dernoeden
}

First author: Department of Plant Science, University of Connecticut, 1376 Storrs Rd., Unit-4067, Storrs 06269; and second author: Department of Natural Resource Sciences and Landscape Architecture, University of Maryland, College Park 20742.

Accepted for publication 2 November 2005.

\begin{abstract}
Kaminski, J. E., and Dernoeden, P. H. 2006. Dead spot severity, pseudothecia development, and overwintering of Ophiosphaerella agrostis in creeping bentgrass. Phytopathology 96:248-254.

Dead spot (Ophiosphaerella agrostis) is a damaging disease of young ( $\leq 6$ years old) creeping bentgrass (Agrostis stolonifera) golf greens. The objectives of this 3-year field study were to determine the peak periods of dead spot activity based on increasing patch diameter and pseudothecia development, and to determine where $O$. agrostis overwinters. Patch

early as the first day of symptom expression and as many as 478 pseudothecia were found in a single patch. Periods of rapid dead spot development coincided with air and soil temperatures ranging from 22 to $26^{\circ} \mathrm{C}$. Increases in patch diameter and pseudothecia development were negligible after late August. Dead spot severity was highest in the year following green construction or fumigation, but then rapidly declined in severity in subsequent years. O. agrostis was capable of overwintering as pseudothecia or as hyphae within or on bentgrass leaf sheaths, crowns, roots, and especially the nodes of stolons.
\end{abstract} diameter generally increased at a linear rate between mid-June and early August. Increases in pseudothecia production closely followed increasing patch diameter. Pseudothecia could be found within necrotic tissue as
Additional keywords: ascocarp, bermudagrass, sexual reproduction.
Dead spot is caused by Ophiosphaerella agrostis Dernoeden, M.P.S. Câmara, N.R. O'Neill, van Berkum, et M.E. Palm and is a disease of creeping bentgrass (Agrostis stolonifera L.) $(1,4)$. Dead spot primarily is a problem on golf course putting greens constructed with sand root zones and generally appears within 1 to 2 years following establishment $(1,4)$. The disease also may occur on older bentgrass putting greens following fumigation with methyl bromide. Since its discovery on a golf putting green in Maryland in 1998, O. agrostis has been isolated from bentgrass putting greens in at least 11 states $(4,6)$. In addition to creeping bentgrass, the pathogen also causes disease in hybrid bermudagrass (Cynodon dactylon [L.] Pers. $\times C$. transvaalensis BurttDavy) putting greens in Texas and Florida $(9,10)$.

On creeping bentgrass grown on golf course putting greens, dead spot initially appears as small, reddish brown or copper-colored spots approximately $1.0 \mathrm{~cm}$ in diameter, which may increase to about 8 to $10 \mathrm{~cm}$ in diameter $(4,6)$. Initial $O$. agrostis infection centers can be confused with other turfgrass diseases such as dollar spot (Sclerotinia homoeocarpa F.T. Bennett), copper spot (Gloeocercospora sorghi Bain \& Edgerton ex Deighton), and Microdochium patch (Microdochium nivale [Fr.] Samuels \& I.C. Hallett). Spots also can mimic damage from black cutworms (Agrotis ipsilon Hufnagel) or the impact of golf balls, which commonly are found on putting greens. As the disease progresses, grass in the center of the spots becomes tan, while leaves in the periphery of expanding patches appear reddish brown. O. agrostis was isolated from bentgrass and bermudagrass leaves, roots,

Corresponding author: J. E. Kaminski; E-mail address: john.kaminski@uconn.edu

* The $\boldsymbol{e}$-Xtra logo stands for "electronic extra" and indicates that the online version contains supplemental material not included in the print edition. Two photos of dead spot are available online.

DOI: 10.1094/PHYTO-96-0248

(C) 2006 The American Phytopathological Society crowns, and stolons, demonstrating that $O$. agrostis colonizes all plant tissues (7). Dark brown to black ectotrophic hyphal masses can be found near or on the nodes of creeping bentgrass stolons, but generally are lacking in the internode region of stolons. In bermudagrass, hyphae generally are found within roots and stolons, and only occasionally are found growing ectotrophically (10).

Once infection occurs, turfgrass in the center of dead spot infection centers dies and often forms pits or depressions, which adversely affect the putting surface. Growth of bentgrass into infected spots is slow and infection centers often remain present throughout the winter until bentgrass growth resumes in the spring. On creeping bentgrass grown in the mid-Atlantic region of the United States, dead spot may occur as early as May and active disease symptoms may be present as late as December (7).

Field observations suggest that dead spot is a polycyclic disease and that $O$. agrostis exists solely in its sexual state $(1,7)$. Although the anamorph of $O$. agrostis has not been observed, pseudothecia often can be found on necrotic leaf, sheath, and stolon tissues $(1,4,7)$. Pseudothecia and ascospores are produced in abundance and serve as a major source of inoculum $(1,7)$. Although other Ophiosphaerella spp. cause several turfgrass diseases, O. agrostis is the only species in which pseudothecia commonly are found in nature (6). Elucidating the peak periods of disease severity and pseudothecia production as well as the ability of $O$. agrostis to overwinter are important factors in understanding the biology of the pathogen.

This study was designed to further investigate the biology of $O$. agrostis and the epidemiology of dead spot. The goals were to identify the period of peak dead spot activity in the field and to evaluate the ability of $O$. agrostis to survive during the winter. The objectives of this field research were to (i) measure the expansion rate of dead spot infection centers over time, (ii) monitor and determine the timing of pseudothecia development, and (iii) determine the ability of $O$. agrostis to overwinter within or on various bentgrass tissues. 


\section{MATERIALS AND METHODS}

Site preparation, inoculation techniques, and data collection. Study year 1. On 20 September 1999, $465 \mathrm{~m}^{2}$ of a United States Golf Association-specified research putting green was seeded $\left(50 \mathrm{~kg}\right.$ of seed ha $\left.{ }^{-1}\right)$ with 'L-93' creeping bentgrass (17). Following seeding, the sites were lightly raked, rolled, and covered with $100 \%$ spunbonded polypropylene (Reemay Inc., Old Hickory, TN) to prevent seeds from dislodging. The area was irrigated to maintain adequate moisture. Covers were removed after bentgrass seedling emergence, which occurred approximately 5 to 8 days after seeding. During autumn 1999, the area received $\mathrm{N}, \mathrm{P}$, and $\mathrm{K}$ at 196,260 , and $54 \mathrm{~kg} \mathrm{ha}^{-1}$, respectively, from a starter fertilizer $\left(\mathrm{N}, \mathrm{P}_{2} \mathrm{O}_{5}\right.$, and $\mathrm{K}_{2} \mathrm{O}$ at 19,25 , and $5 \%$, respectively; The Scotts Company, Marysville, $\mathrm{OH}$ ). The nitrogen consisted of $4.3 \%$ ammoniacal $\mathrm{N}, 7.4 \%$ urea $\mathrm{N}, 6.3 \%$ other watersoluble N, and $1.0 \%$ water-insoluble N. Superphosphate (0-45 $\left.\mathrm{P}_{2} \mathrm{O}_{5}-0\right)$ and $\mathrm{K}_{2} \mathrm{SO}_{4}\left(0-0-50 \mathrm{~K}_{2} \mathrm{O}\right)$ were the $\mathrm{P}$ and $\mathrm{K}$ sources, respectively. Plots were mowed threes times weekly to a height of 4 to $5 \mathrm{~mm}$. The area was routinely irrigated, vertical mowed, and topdressed throughout the study. On 8 October 1999, the 'L-93' area was inoculated with $O$. agrostis isolate OpVA-1. Inoculum consisted of a mix of tall fescue (Festuca arundinacea Schreb.) seed and wheat (Triticum aestivum L.) bran (50:50, vol/vol), which was prepared as previously described (7). Approximately $0.5 \mathrm{~g}$ of the $O$. agrostis inoculum was placed below the thatch and at the soil surface on 0.9 -m centers.

Microdochium patch (Microdochium nivale) was active in the site in April and May 2000. Therefore, a single application of $9.2 \mathrm{~kg}$ a.i. $\mathrm{ha}^{-1}$ chlorothalonil (tetrachloroisophthalonitrile) plus $9.2 \mathrm{~kg}$ a.i. $\mathrm{ha}^{-1}$ iprodione (3-(3,5-dichlorophenyl)- $N$-(1-methylethyl)-2,4-dioxo-1-imidazolidinecarboxamide) was applied on 1 June.

When disease symptoms initially appeared, 15 infection centers were chosen arbitrarily and measurements were made every 2 to 5 days between 10 June and 14 July 2000. Disease severity was assessed by measuring patch diameter of individual infection centers in two directions with a ruler. Mean patch diameter of each infection center was used for statistical analyses. Pseudothecia also were counted within each patch with a portable microscope at a magnification of $\times 25$ (Macroscope 25, Ben Meadows Company, Janesville, WI). On 17 July, newly appearing infection centers $(n=14)$ were selected and patch diameters were measured and pseudothecia were counted until 1 September 2000.

Study year 2. On 20 September 1999, a 465- $\mathrm{m}^{2}$ area was seeded to 'Providence' creeping bentgrass using the previously mentioned methods and maintained similar to the study site for year 1. A previously reported cultivar evaluation study revealed that both cultivars had similar levels of dead spot susceptibility (7). In 2001, the study site was inoculated with two $O$. agrostis isolates (OpMD-9 and OpVA-1) on 12 March and the inoculum was placed below the thatch at the soil surface in a grid pattern spaced approximately every $1.5 \mathrm{~m}$.

Triadimefon (1-(4-chlorophenoxy)-3,3-dimethly-1-(1H-1,2,4triazol-1-yl)-2-butanone) (2.4 kg a.i. ha $\left.{ }^{-1}\right)$, which provides little or no dead spot control, was applied preventively three times to control dollar spot (16). Sod webworm (Crambus spp.) and black cutworm were controlled as needed with pyrethroid insecticides. Wetting agents were applied periodically to control hydrophobic soil conditions beginning in June 2001.

To monitor disease development over the course of the entire season, new infection centers $(n=4)$ were selected periodically throughout 2001. New infection centers appearing on 1 June, 20 July, 20 August, and 3 and 21 September were arbitrarily chosen and the diameter of infection centers and the development of pseudothecia within each were monitored until 2 November 2001.

Study year 3. Due to a general decrease in disease activity in 2001, the 2002 study site was fumigated. On 23 August 2001, a $465-\mathrm{m}^{2}$ area was vertically mowed to a $1 \mathrm{~cm}$ depth, covered with polyethylene, and fumigated with methyl bromide ( $98 \%$ methyl bromide plus $2 \%$ chloropicrin). On 25 August, covers were removed and the area was overseeded with 'L-93' creeping bentgrass on 30 August. The aforementioned starter fertilizer was applied several times between September and November 2001 to supply a total of $196 \mathrm{~kg}$ of $\mathrm{N} \mathrm{ha}^{-1}$. On 21 March 2002, the area was inoculated with $O$. agrostis isolates OpOH-1 and OpVA-1. On 4 April 2002, the area received $37 \mathrm{~kg}$ of $\mathrm{N} \mathrm{ha}^{-1}$ from the starter fertilizer. Between 26 April and 11 October, a total of $135 \mathrm{~kg}$ of $\mathrm{N} \mathrm{ha}^{-1}$ from urea and nitrate-nitrogen sources was applied to the study area. Similar to the previous 2 years, various pesticides were applied to the study site in an effort to minimize damage from other pests. To control dollar spot, $9.2 \mathrm{~kg}$ a.i. $\mathrm{ha}^{-1}$ chlorothalonil was applied on 1 May and $2.4 \mathrm{~kg}$ a.i. ha ${ }^{-1}$ triadimefon was applied on 24 May, 14 June, and 6 September. To control black cutworm, $6.7 \mathrm{~kg}$ a.i. ha ${ }^{-1}$ chlorpyrifos was applied on 18 May.

In 2002, dead spot infection centers were selected at random throughout the year and disease development was monitored until 31 October. New infection centers $(n=4)$ were selected on 13 and 27 May, 18 June, 8 July, 12 August, and 9 September and data were collected as previously mentioned for 2001.

In all years, air and soil temperatures were monitored between 1 May and 31 October. Air temperature $\left(\mathrm{T}_{a}\right)$ was measured with a thermistor (model HMP35C, Campbell Scientific, Logan, UT), which was placed $30 \mathrm{~cm}$ above the plant canopy. Soil temperature $\left(\mathrm{T}_{s}\right)$ was measured by averaging the data from two thermistors (model 107B, Campbell Scientific, Logan, UT) placed $2.5 \mathrm{~cm}$ below the turfgrass canopy at the thatch and soil interface. All instruments were programmed to measure environmental conditions at 2-min intervals and mean $\mathrm{T}_{a}$ and $\mathrm{T}_{s}$ were recorded every 60 min. Day length data collected for College Park, MD, were provided by the United States Naval Observatory located in Washington, D.C.

Statistical analyses. A square root transformation of pseudothecia count data was completed prior to analyses. Regression was used to determine the rate of increase for the number of pseudothecia and patch diameter during each of the three study years. Regression analyses were performed on patch diameter or numbers of pseudothecia per patch and day of the year, and slope coefficients were compared using the method described by Neter and Wasserman (11).

The area under the disease progress curve (AUDPC) also was determined for patch diameter and pseudothecia development. Dates used to calculate AUDPC values were 1 June to 2 November 2001 and 13 May to 31 October 2002. In 2000, patch diameter and pseudothecia counts were collected for shorter periods; therefore, these data were not included in the AUDPC analyses. All AUDPC values were subjected to analysis of variance using the MIXED procedure in SAS (SAS Institute, Cary, NC; 13). The AUDPC values were calculated using the formula: $\Sigma\left[\left(y_{i}+\right.\right.$ $\left.\left.y_{i+1}\right) / 2\right]\left(t_{i+1}-t_{i}\right)$, where $i=1,2,3 \ldots n-1, y_{i}$ is the diameter (millimeters) of $O$. agrostis infection centers or number of pseudothecia $\operatorname{spot}^{-1}$, and $t_{i}$ is the time of the $i$ th rating (2).

To determine the impact of accumulating heat leading up to the period of peak disease activity, cumulative degree-days (DD) were computed using $\mathrm{T}_{a}$ and $\mathrm{T}_{s}$. Accumulated $\mathrm{DD}$ began on 1 May of each year and were calculated by the following equation: $\mathrm{DD}=\sum^{n}\left(\mathrm{~T}_{(s \text { or } a)}\right)-\left(\mathrm{T}_{b}\right)$, where $\mathrm{T}_{(s \text { or } a)}$ is the mean daily soil $(s)$ or air $(a)$ temperature, $\mathrm{T}_{b}$ is the base temperature, and $n$ is the number of days elapsed since 1 May (12).

In planta distribution and overwintering of $\boldsymbol{O}$. agrostis. The survival of $O$. agrostis within or on plants was determined by attempting to isolate the pathogen from various creeping bentgrass tissues and pseudothecia. Attempts to isolate $O$. agrostis from creeping bentgrass previously infected by the pathogen were made between 31 January and 26 June 2001 (year 1), 31 May 
2001 and 1 March 2002 (year 2), and 20 June 2002 and 26 June 2003 (year 3). Three to four infection centers were removed from the field and immediately prepared for study. Symptomatic bentgrass plants from the edge of diseased spots were removed and green and bronze/tan leaves, leaf sheaths, roots, stolons, and crowns were prepared for pathogen isolation. When present, pseudothecia were removed from dead or decaying tissue. Isolation of $O$. agrostis from all tissues and pseudothecia was attempted according to previously described methods (7). Briefly, infected plant tissue was sectioned into 3- to 6-mm-long pieces, surface disinfested in $0.5 \%$ sodium hypochlorite for $60 \mathrm{~s}$, and washed three times for $30 \mathrm{~s}$ in sterile distilled water. Tissue then was blotted dry on sterile filter paper, allowed to grow on antibiotic water agar for 3 to 5 days, and transferred to potato dextrose agar. Positive identification of $O$. agrostis was based on the growth rate and colony color described by Kaminski et al. (9). A total of 10 tissue sections of each tissue type or pseudothecia were chosen for each isolation date, and data were reported as a percentage of successful $O$. agrostis isolations.

To track the progression of the pathogen within the plant at various times of the year, regression analyses were conducted on the percentage of successful $O$. agrostis isolations using SAS (12). To perform regression analyses, dates were expressed as numeric values representing accumulated days beginning with the first day of the year for each study. Regression analyses were performed on numeric dates ranging from day 151 (31 May) to day 542 (26 June). To prevent misinterpretation of regression lines for the data from all 3 years, stepwise regression analyses were performed separately on data collected from 2001 to 2002 and 2002 to 2003 to determine the best fit line for each year. Significant polynomic transformations of accumulated numeric days for each year were selected and regression analyses again were performed on all isolation data collected during the 3 years.

\section{RESULTS}

Study year 1. Dead spot symptoms first appeared on 8 June 2000. Infection centers first appearing on 10 June were monitored further. Patch diameter measured on 10 June $(n=15)$ increased from an average initial diameter of 39 to $63 \mathrm{~mm}$ by the final rating date (14 July) (Fig. 1). Although pseudothecia initially were not observed within these infection centers, an average of

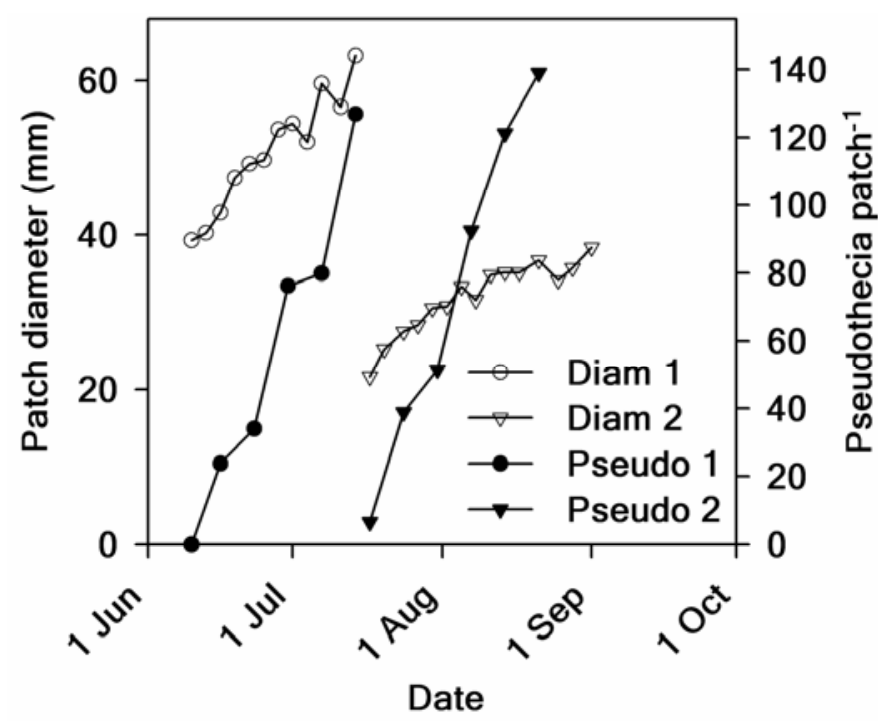

Fig. 1. Patch diameter (Diam) and number of pseudothecia (Pseudo) within dead spot infection centers in 2000. Each symbol represents the mean patch diameter or pseudothecia count within independently monitored infection centers. New infection centers appeared on 10 June (diameter and pseudothecia $1, n=15$ ) and 17 July (diameter and pseudothecia 2, $n=14$ ).
24 pseudothecia per infection center was observed on 16 June (6 days after the appearance of initial symptoms). Pseudothecia continued to develop in necrotic tissue within patches, and an average of 127 pseudothecia were observed on 14 July.

A second set of infection centers $(n=14)$ appearing on 17 July were monitored until 1 September. On 17 July, patches averaged $22 \mathrm{~mm}$ in diameter and increased to $38 \mathrm{~mm}$ by the final rating date (Fig. 1). Pseudothecia were present within several infection centers when symptoms first became visible, and an average of 139 pseudothecia spot $^{-1}$ were present on 21 August. In 2000, no new infection centers appeared after 11 October.

Study year 2. Few infection centers developed in the 1999 seeded 'Providence' bentgrass and disease severity generally was low in 2001. O. agrostis infection centers first appeared on 31 May 2001. Four infection centers appearing on 1 June were marked and patch diameter and pseudothecia development were monitored until 2 November. Average patch diameter increased from $13 \mathrm{~mm}$ on 1 June to $25 \mathrm{~mm}$ on 18 June (Fig. 2A). Mean pseudothecia production within these patches, however, was low ( $\leq 8$ per patch) until the end of June (Fig. 2B). Between 29 June and 16 July, the average number of pseudothecia within patches increased to 101 . After $16 \mathrm{July}$, the average number of pseudothecia patch ${ }^{-1}$ rapidly declined and an average of only 5 pseudothecia patch $^{-1}$ were observed by the final rating date ( 2 November). Four additional sets of infection centers $(n=4)$ were selected between 20 July and 21 September and monitored until 2 November. Although disease symptoms were observed, there was little or no increase in patch diameter ( 0 to $4 \mathrm{~mm}$ ) from these infection centers (Fig. 2A). In addition, very few pseudothecia $(\leq 3)$ were observed within monitored infection centers appearing in July or August. Pseudothecia (7 to 17) were observed, however, within new infection centers appearing on 3 and 21 September (Fig. 2B). Similar to 2000, no new infection centers appeared after early October.

Study year 3. Following fumigation in August 2001, dead spot incidence in 2002 was high and results were similar to those observed in 2000. In 2002, new infection centers were apparent within inoculated spots on 12 May (Fig. 2C). Few new infection centers appeared between early May and early June; however, numerous new infections were observed between early June and mid-August. Despite the continued appearance of new infection centers between early May and early June, patch diameter $(n=8)$ did not begin to increase until mid-June (Fig. 2C). Patch diameter continued to increase in all monitored spots $(n=16)$ until early to mid-August. Little or no increase in patch diameter was observed in any spots after mid-August, and no new infection centers developed after 9 October.

Although pseudothecia were found in the introduced inoculum in April, pseudothecia were not observed within necrotic bentgrass tissues until 9 June (Fig. 2D). Maximum pseudothecia within spots $(n=12)$ appearing between 13 May and 18 June occurred by mid-August, and up to 478 fruiting bodies were observed within a single patch. Few pseudothecia $(\leq 11)$ developed within new infection centers appearing on 12 August or 9 September.

Regression analyses and AUDPC. In 2000, patch diameter and pseudothecia counts were measured between 10 June and 14 July $(n=15)$ and 17 July and 14 August $(n=14)$. Although variation in the initial diameter of patches was great (range $=20$ to $62 \mathrm{~mm}$ ), the initial infection centers appearing on 10 June (day 162) increased linearly throughout the period $\left(R^{2}=0.27 ; P<\right.$ 0.0001) (Fig. 3A). A similar linear increase in patch diameter $\left(R^{2}=0.46 ; P<0.0001\right)$ initially was observed from infection centers appearing on 17 July (day 199). The patch diameter of all infection centers increased linearly from 10 June to 14 August (day 162 to day 227). As was the case with patch diameter, pseudothecia also developed linearly in both sets of infection centers $\left(R^{2}=0.65\right.$ and $\left.0.70 ; P<0.0001\right)$ (Fig. 3B). 
After an initial increase in patch diameter, infection centers $(n=4)$ appearing on 1 June 2001 expanded at a slow rate and only reached a mean patch diameter of $30 \mathrm{~mm}$. Regression analysis of these infection center diameters was weakly linear $\left(R^{2}=\right.$ $0.14 ; P=0.0013$ ) between June and August (Fig. 3A). Unlike 2000 , the patch diameter of infection centers appearing in late July 2001 did not increase in size. Pseudothecia developed within the initial infection centers, but unlike 2000, a linear increase in the number of pseudothecia only occurred for a short period (29 June to 20 July; day 180 to day 201) (Fig. 3B).

Although $O$. agrostis infection centers first appeared on 12 May 2002 in study year 3, the linear growth phase of these infection centers did not occur until approximately mid-June (Fig. 3A). Regardless of when infection centers first appeared, patch diameters increased at a similar linear rate $\left(R^{2}=0.63\right.$ to $0.92 ; P<$ 0.0001 ) between 14 June and 12 August 2002 (day 165 and day 224). Patch diameter of infection centers appearing on 12 August and 9 September remained small and patches did not appreciably increase in size throughout the remainder of the season. In 2002, the linear stage of pseudothecia production $\left(R^{2}=0.49\right.$ to $0.90, P<$ 0.0001 ) began in late June, approximately 7 to 10 days following the linear increase in patch diameter (Fig. 3). Additionally, the number of pseudothecia patch ${ }^{-1}$ continued to increase until late August, approximately 2 weeks after increases in patch diameter had ceased. The rate of increasing patch diameter (slope coefficient) of combined data for each year was similar in 2000 (first year after establishment) and 2002 (first year following methyl bromide fumigation). The rate of increasing patch diameter from infection centers appearing in 2001 (second year following estab- lishment), however, was significantly different $(P<0.0001)$ from the other years.

Differences in total disease (AUDPC) were observed among starting dates for monitoring new infection centers in 2001 and $2002(P<0.0001)$ (Table 1). Based on patch diameter data collected from infection centers in 2001, disease severity (AUDPC = 784) was greatest when infection centers developed on 1 June. There were no significant differences in the AUDPC values (AUDPC $=139$ to 239) from infection centers appearing between 20 July and 21 September 2001. Unlike 2001, dead spot was very severe in 2002 and total disease varied among infection center sets occurring throughout the season (May to September). Disease severity (AUDPC $=1,032$ to 1,049 ) was greatest for infection centers $(n=8)$ appearing in May 2002, but AUDPC values were significantly less for infection centers appearing on 18 June, 8 July, and 12 August. Disease severity (AUDPC $=183$ and 186) was low for infection centers appearing in August and September.

Total pseudothecia development was greatest within infection centers first appearing on 1 June 2001 (Table 1). Pseudothecia were produced in very low numbers within infection centers appearing between 20 July and 21 September. In 2002, prodigious numbers of pseudothecia developed within infection centers appearing between 13 May and 18 June. Moderately high pseudothecia numbers were observed over the data collection period within infection centers appearing on 8 July 2002.

DD model. The development of a DD model was attempted based on the delay in time between the appearance of the initial symptoms and the time when new infection centers began to increase at a linear rate. Kaminski et al. (9) found that dead spot
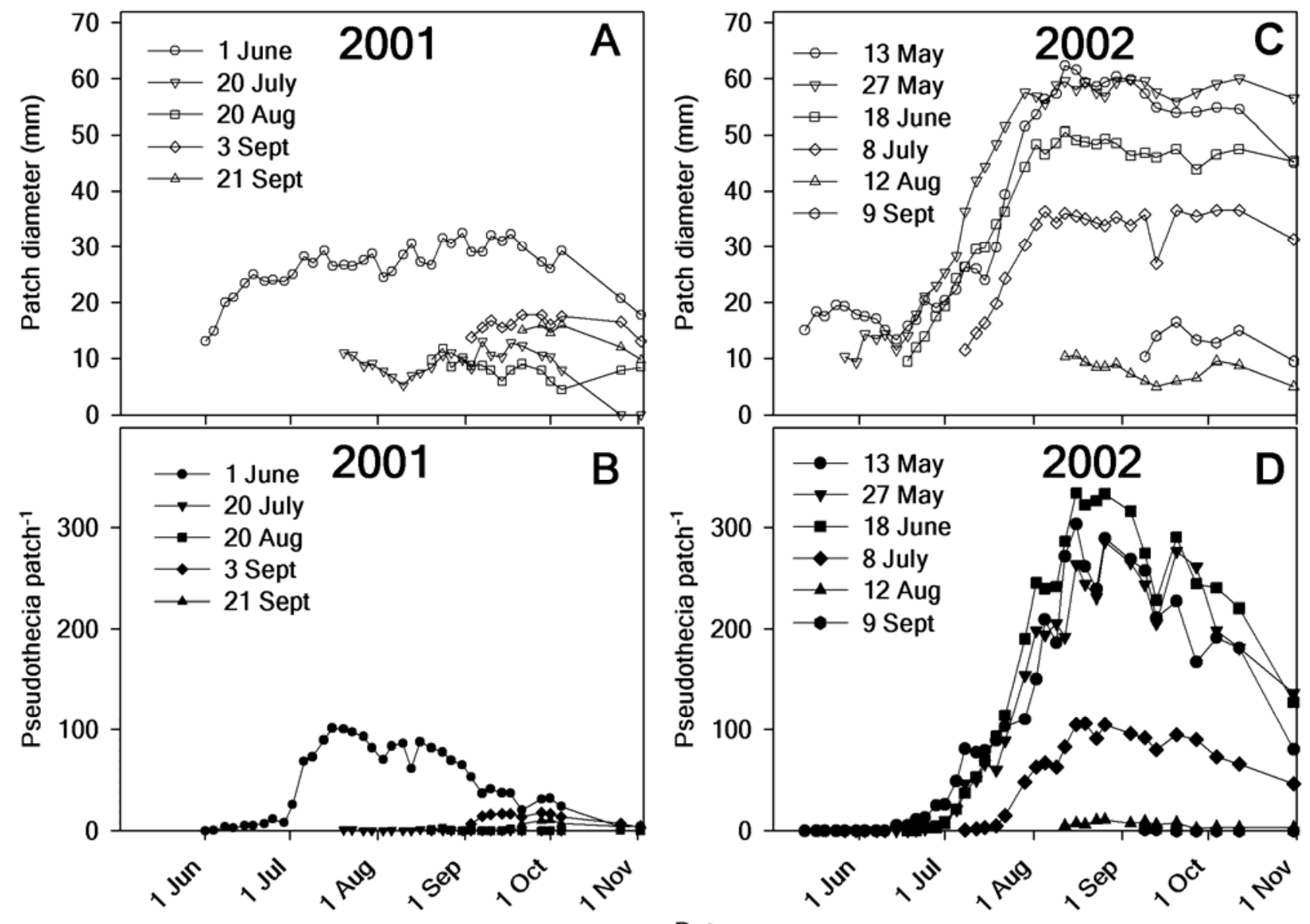

Date

Fig. 2. Patch diameter (A and $\mathbf{C})$ of and pseudothecia number (B and $\mathbf{D})$ within dead spot infection centers in 2001 and 2002. Each symbol represents the mean patch diameter or pseudothecia count within four independently monitored infection centers. Days listed in the legend indicate dates in which infection centers first appeared. 
symptoms redeveloped in winter-dormant, infected creeping bentgrass plants that were incubated at temperatures $\geq 20^{\circ} \mathrm{C}$. Although no reactivation of symptoms was visible when infected creeping bentgrass was incubated at $15^{\circ} \mathrm{C}$, the pathogen was isolated from leaf tissue. In this study, disease symptoms generally did not appear at temperatures $\leq 15^{\circ} \mathrm{C}$. Therefore, a base temperature of $15^{\circ} \mathrm{C}$ was selected for the accumulated DD model.

DD totals of 218 (2000), 390 (2001), and 285 (2002) were associated with the period in which pseudothecia began to increase at a linear rate (Table 2). Due to the reduced disease severity and limited increase in patch diameter, DD were not calculated for patch diameter data in 2001. Based on soil temperature data collected in 2000 and 2002, the accumulated DD associated with an increase in patch diameter was 218 and 213, respectively. A similar trend in DD was observed when air temperature was used; however, fewer DD generally were accumulated prior to increases in patch diameter or pseudothecia production.

In planta distribution and overwintering of $\boldsymbol{O}$. agrostis. Isolation of $O$. agrostis primarily was attempted for 1 year following the development of initial symptoms within each site. Data collected from all 3 years were combined and the percentages of successful isolations of $O$. agrostis from bentgrass tissue and pseudothecia were determined (Fig. 4). Isolation of $O$. agrostis from green tissue only was successful during periods of highest disease activity (Fig. 4A). Percent isolation of the pathogen from bronze or tan leaves (Fig. 4B) or from discolored leaf sheaths (Fig. 4C) generally was highest after the appearance of initial symptoms and declined during the autumn months. During the winter months, isolation of $O$. agrostis from the aforementioned tissues generally was unsuccessful $(\leq 20 \%)$. Isolation of $O$. agrostis from root tissue varied throughout the year, but percent isolation
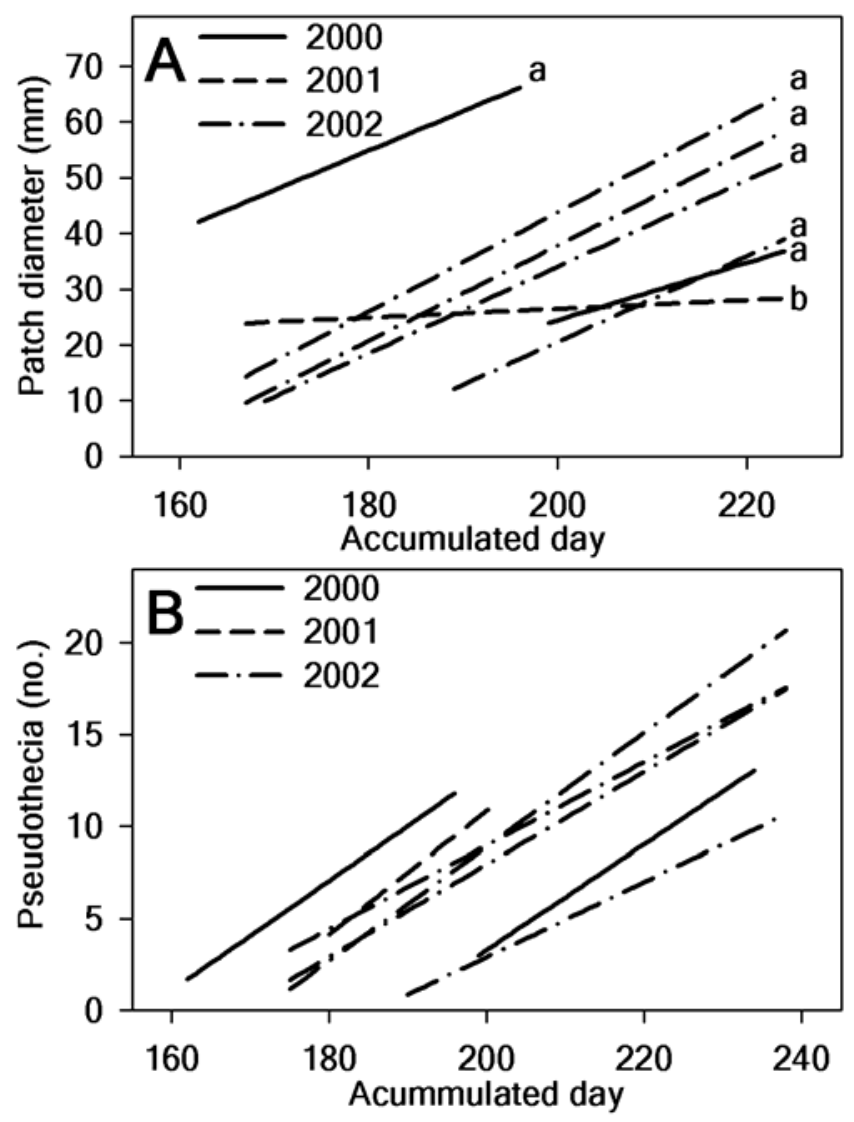

Fig. 3. Predicted linear growth phase of $\mathbf{A}$, dead spot patch diameter and $\mathbf{B}$, pseudothecia production between accumulated day 162 and 238,2000 to 2002. Regression lines followed by different letters have significantly different slope coefficients $(P<0.0001)$ according to Tukey's protected least significant difference test. generally declined from the time of initial symptom expression (100 to 50\%) until the final isolation attempt in the second year (0 to 60\%) (Fig. 4D). Attempts to isolate the pathogen directly from pseudothecia also were made throughout the study. Pseudothecia, however, were not always present in the collected samples. Isolation of $O$. agrostis from pseudothecia was greatest during late summer and autumn, but declined throughout the winter and spring (Fig. 4E). Pseudothecia generally were not observed or isolation was unsuccessful by June or July in the year following initial symptoms. O. agrostis generally was isolated in greatest percentages from stolon tissue (Fig. 4F). Isolation of the pathogen from bentgrass stolons commonly was $\geq 80 \%$ throughout the autumn. A decline in percent isolation from stolon tissue occurred during the winter months; however, the pathogen was isolated from at least 3 of 10 stolons on all dates. Isolation of $O$. agrostis from crown tissue (Fig. 4G) followed a pattern similar to that of the stolons, although the frequency of isolation from crown tissues generally was lower. Similar to isolation from leaf sheaths (Fig. 4C), isolation of the pathogen from bentgrass stolons (Fig. 4F) and crowns (Fig. 4G) increased during late spring and early summer of the second year. Despite this increase in successful isolations from plants in late April and early May in the second year, active dead spot symptoms or new infection centers seldom were visible.

\section{DISCUSSION}

Similar to previous observations, dead spot development in this study was most severe during the year following construction and seeding of the research putting green or following fumigation and reseeding $(3,7)$. Disease severity was very low in 2001 following

TABLE 1. Area under the disease progress curve (AUDPC) values for patch diameter and Ophiosphaerella agrostis pseudothecia production in creeping bentgrass, 2001-2002

\begin{tabular}{|c|c|c|}
\hline \multirow[b]{2}{*}{ Date of initial infection ${ }^{y}$} & \multicolumn{2}{|c|}{ AUDPC } \\
\hline & Patch diameter & Pseudothecia patch ${ }^{-1}$ \\
\hline \multicolumn{3}{|l|}{2001} \\
\hline 1 June & $784 a^{z}$ & $879 a$ \\
\hline 20 July & $231 \mathrm{~b}$ & $8 \mathrm{~b}$ \\
\hline 20 August & $168 \mathrm{~b}$ & $12 \mathrm{~b}$ \\
\hline 3 September & $239 \mathrm{~b}$ & $178 \mathrm{~b}$ \\
\hline 21 September & $139 \mathrm{~b}$ & $90 \mathrm{~b}$ \\
\hline \multicolumn{3}{|l|}{2002 (fumigated site) } \\
\hline 13 May & $1,049 \mathrm{a}$ & $1,548 \mathrm{a}$ \\
\hline 27 May & $1,032 \mathrm{a}$ & $1,565 \mathrm{a}$ \\
\hline 18 June & $849 b$ & $1,700 \mathrm{a}$ \\
\hline 8 July & $638 c$ & $806 \mathrm{~b}$ \\
\hline 12 August & $186 \mathrm{~d}$ & $145 \mathrm{bc}$ \\
\hline 9 September & $183 \mathrm{~d}$ & $3 c$ \\
\hline
\end{tabular}

y New infection centers were marked periodically throughout the study, and patch diameter and the number of pseudothecia within each patch were recorded.

${ }^{\mathrm{z}}$ For each year, means in a column followed by the same letter are not significantly different $(P \leq 0.05)$ according to Tukey's protected least significant difference test.

TABLE 2. Accumulated degree-days (DD) using soil $\left(\mathrm{T}_{s}\right)$ and air $\left(\mathrm{T}_{a}\right)$ temperature from 1 May until the linear increase in patch diameter and linear growth period of pseudothecia production for 3 years

\begin{tabular}{lcccccc}
\hline & \multicolumn{2}{c}{ Patch diameter } & & \multicolumn{2}{c}{ Pseudothecia } \\
\cline { 2 - 3 } \cline { 5 - 6 } Year & $\mathrm{DD}_{\mathrm{T} s}$ & $\mathrm{DD}_{\mathrm{T} a}$ & & $\mathrm{DD}_{\mathrm{T} s}$ & $\mathrm{DD}_{\mathrm{T} a}$ \\
\hline 2000 & 218 & 178 & & 218 & 178 \\
2001 & $-{ }^{\mathrm{z}}$ & - & & 390 & 295 \\
2002 & 213 & 177 & & 285 & 248 \\
\hline
\end{tabular}

${ }^{\mathrm{z}}$ Data in 2001 were not included in determining accumulated DD due to reduced disease severity and limited increase in patch diameter during the year. 
seeding in 1999. Although 'Providence' creeping bentgrass was used in the second year (2002), previously reported cultivar evaluation data revealed that both cultivars were equally susceptible to $O$. agrostis (7). Additionally, molecular analyses of isolates collected from the study site revealed a broad genetic diversity, thus indicating that the three isolates used to inoculate the study probably had little impact on disease severity (6). The rapid decline in dead spot incidence and severity likely was due to factors other than differences in cultivar susceptibility or pathogenicity of the isolates.

Despite the 2001 fumigation of the study site and an increase in dead spot severity in 2002, very few new infection centers were observed within this site in 2003. These observations again demonstrate that a decline in dead spot incidence and severity frequently occurs in the year following initial infection $(7,9)$. Kaminski and Dernoeden (7) suggested that dead spot activity may be promoted in sand-based root zones with initially low soil microbial activity, but noted that low inoculum potential may impact disease incidence in the second year. Based on the results of this study, it appears that secondary inoculum is drastically reduced following the first year of infection. Inoculum potential from the ascospores at the study site, however, generally was high (data not shown). All three study sites were located adjacent to each other; therefore, inoculum in the form of ascospores was present each year. The reduction in disease severity, therefore, likely is the result of factors other than ascospore inoculum density such as turf age and possibly an increase in populations of microbial antagonists. A slower decline occurs with take-all patch (Gaeumannomyces graminis (Sacc.) Arx and D. Olivier var. avenae (E. M. Turner) Dennis) in bentgrass turf $(14,15)$. The decline of take-all in wheat (5) and Agrostis spp. (18) has been attributed to an increase in populations of bacterial antagonists.

New $O$. agrostis infection centers appeared as early as May, but infection centers only increased in size and most pseudothecia only were produced during a relatively short period between June and August. Monthly mean air and soil temperatures for June, July, and August ranged from 22 to $26^{\circ} \mathrm{C}$. Although new infection centers continued to appear into early October of all 3 years, infection centers appearing after late August or early September remained small and few pseudothecia developed within these patches. Therefore, the greatest disease occurred from spots or patches developing earlier in each season. The impact of inoculation on the development of initial infection centers is unknown, but may have resulted in the early development of dead spot infection centers in the field. The predicted period of linear increase in patch diameter and pseudothecia development, therefore, may be more indicative of natural dead spot progression in uninoculated situations. The use of the DD model developed in this study may be a more appropriate indicator of the period immediately prior to peak dead spot activity. Although the range of accumulated DD developed to predict the period in which pseudothecia and patch diameter began to increase was small, further study in different geographic regions is warranted with respect to the use of DD for predicting the peak period of dead spot activity.

Pseudothecia developed at a similar rate within each infection center over the course of the study. In the second year of the study (2001; area seeded in 1999), however, this linear growth period was shortened and only lasted approximately 3 weeks. In 2000 and 2002 (first year after construction and first year after fumigation, respectively), pseudothecia production within infected tissues coincided with increasing patch diameter. In laboratory studies, pseudothecia developed when incubated in constant light and under a range of temperatures $\left(13\right.$ to $\left.28^{\circ} \mathrm{C}\right)$, but did not develop in the dark (9). Pseudothecia generally began to appear within infected bentgrass tissue in June and maximum numbers of pseudothecia were produced by mid-August during conditions of long day lengths (13.5 to $14.9 \mathrm{~h} \mathrm{day}^{-1}$ ) and elevated air (22 to $\left.26^{\circ} \mathrm{C}\right)$ and soil $\left(24\right.$ to $\left.26^{\circ} \mathrm{C}\right)$ temperatures. Daily increases in patch diameter and pseudothecia production, however, were not correlated with daily temperatures or day lengths (data not shown). Greatest pseudothecia production was achieved soon after (1 to 2 weeks) patch size reached its maximum. It is unclear, however, if a minimum period of light or day length or an interaction between temperature and day length trigger the initiation or are necessary for the production of $O$. agrostis pseudothecia. In bermudagrass, pseudothecia can be found within necrotic tissues as early as March in Texas and Florida $(6,9,10)$, suggesting that temperature may be more important than day length in their development.

It was observed in previous laboratory studies that pseudothecia within inactive winter patches could germinate directly to produce mycelia (9). Immature ascospores also could be found within pseudothecia during the winter months. Based on results of this study, however, viable cells within pseudothecia appear to decline rapidly overtime. $O$. agrostis can be found throughout the entire plant during periods of peak disease activity, but primarily over-
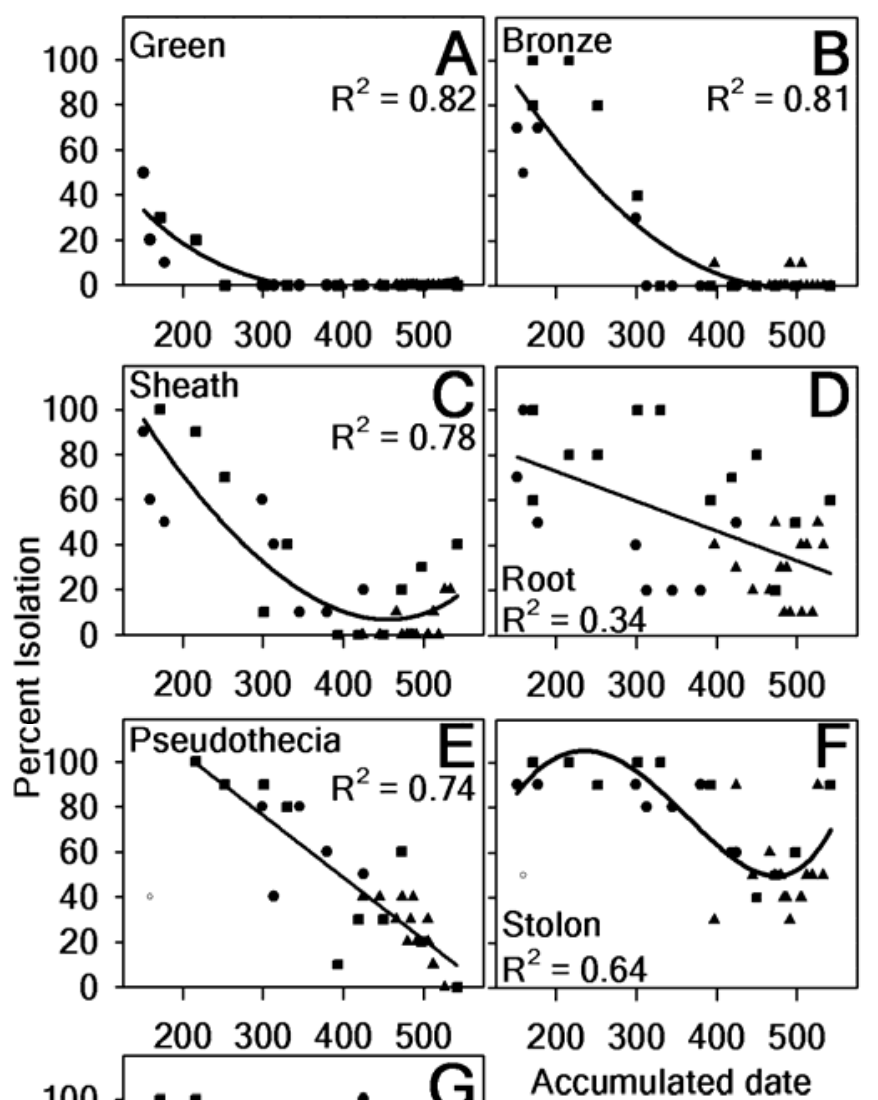

200300400500

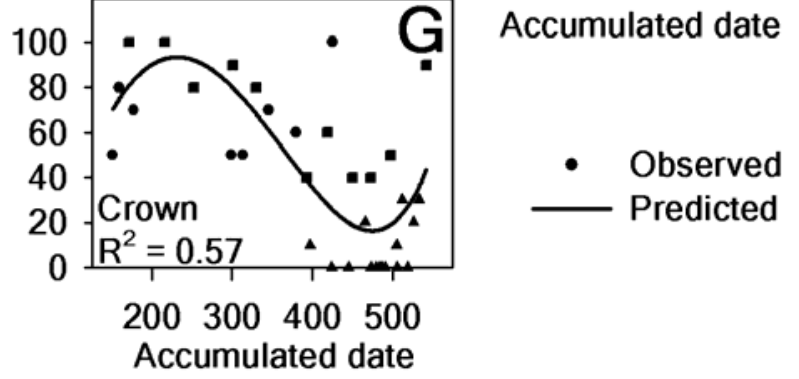

Fig. 4. Isolation of Ophiosphaerella agrostis from $\mathbf{A}$, green or $\mathbf{B}$, bronze leaves; C, leaf sheaths; D, roots; E, pseudothecia; F, stolons; and $\mathbf{G}$, crowns of infected creeping bentgrass plants. Pathogen isolation was attempted for 1 year following initial dead spot symptoms (2000 to $2001=\boldsymbol{\Delta}, 2001$ to $2002=\mathbf{0}$, and 2002 to $2003=\mathbf{\square}$ ). Open symbols represent outliers that were not included in the regression analyses. Accumulated days began with 1 during the first year of infection and 366 for 1 January during the second year of infection. 
winters in bentgrass tissue residing near or below the soil surface (i.e., roots, stolons, and crowns). The survival of the pathogen in or on underground tissue likely occurs in response to the temperature buffering capacity of thatch and soil and probably other factors. In the year following initial symptom expression, regression analysis revealed an increase in the percentage of successful $O$. agrostis isolations from leaf sheath, crown, and stolon tissue. Despite this survival and apparent growth of the pathogen on the aforementioned tissues between late March and into June in the second year, little or no reactivation of disease symptoms occurred in the second year of each study. It should be noted that dead spot has been observed on greens as old as 6 years and that new $O$. agrostis infections may be promoted by certain watersoluble nitrogen sources (urea, $\mathrm{Ca}\left(\mathrm{NO}_{3}\right)_{2}, \mathrm{KNO}_{3}$ ) during the characteristic decline phase of the disease $(7,8)$. While the disease generally declines in the second year, there are other known and unknown factors that may promote dead spot for several years following initial symptom expression.

\section{ACKNOWLEDGMENTS}

We thank the United States Golf Association for financial support, and A. Grybauskas and E. C. Synkowski for the helpful comments and assistance.

\section{LITERATURE CITED}

1. Câmara, M. P. S., O'Neill, N. R., van Berkum, P., Dernoeden, P. H., and Palm, M. E. 2000. Ophiosphaerella agrostis sp. nov. and its relationship to other species of Ophiosphaerella. Mycologia 92:317-325.

2. Campbell, C. L., and Madden, L. V. 1990. Introduction to Plant Disease Epidemiology. Wiley, New York.

3. Dernoeden, P. H. 2000. Creeping Bentgrass Management: Summer Stress, Weeds, and Selected Maladies. Ann Arbor Press, Chelsea, MI.

4. Dernoeden, P. H., O'Neill, N. R., Câmara, M. P. S., and Feng, Y. 1999. A new disease of Agrostis palustris incited by an undescribed species of Ophiosphaerella. Plant Dis. 83:397.
5. Huber, D. M., and McCay-Buis, T. S. 1993. A multiple component analysis of the take-all disease of cereals. Plant Dis. 77:437-446.

6. Kaminski, J. E. 2004. Biology of Ophiosphaerella agrostis, epidemiology of dead spot, and a molecular description of the pathogen. Ph.D. diss. University of Maryland, College Park.

7. Kaminski, J. E., and Dernoeden, P. H. 2002. Geographic distribution, cultivar susceptibility, and field observations on bentgrass dead spot. Plant Dis. 86:1253-1259.

8. Kaminski, J. E., and Dernoeden, P. H. 2005. Nitrogen source impact on dead spot (Ophiosphaerella agrostis) recovery in creeping bentgrass. Int. J. Turfgrass Sci. 10:214-223.

9. Kaminski, J. E., Dernoeden, P. H., O'Neill, N. R., and Momen, B. 2002. Reactivation of bentgrass dead spot and growth, pseudothecia production, and ascospore germination of Ophiosphaerella agrostis. Plant Dis. 86:1290-1296.

10. Krausz, J. P., White, R. H., Foerster, W., Tisserat, N. A., and Dernoeden, P. H. 2001. Bermudagrass dead spot: A new disease of bermudagrass caused by Ophiosphaerella agrostis. Plant Dis. 85:1286.

11. Neter, J., and Wasserman, W. 1974. Applied Linear Statistical Models. Richard D. Irwin, Inc., Homewood, IL.

12. Ritchie, J. T., and NeSmith, D. S. 1991. Temperature and crop development. Pages 5-29 in: Modeling Plant and Soil Systems. J. Hanks and J. T. Ritchie, eds. Agron. Monogr. 31. ASA, CSSA, and SSSA, Madison, WI

13. SAS Institute. 2000. SAS OnlineDoc. Version 8, SAS Institute, Cary, NC.

14. Smiley, R. W., Dernoeden, P. H., and Clarke, B. B. 2005. Take-all patch. Pages 102-105 in: Compendium of Turfgrass Diseases. 3rd ed. The American Phytopathological Society, St. Paul, MN.

15. Smith, J. D., Jackson, N., and Woolhouse, A. R. 1989. Take-all patch (formerly Ophiobolus patch). Pages 137-146 in: Fungal Diseases of Amenity Turf Grasses. EFN Spon, New York.

16. Towers, G. W., Majumdar, P. R., Weibel, E. N., Frasier, C. L., Vaiciunas, J. N., Peacos, M., and Clarke, B. 2000. Evaluation of chemical and biological fungicides for the control of bentgrass dead spot in creeping bentgrass. Rutgers Turfgrass Proc. 32:211-215.

17. United States Golf Association Green Section Staff. 1993. USGA recommendations for a method of putting green construction. USGA Green Section Record 31:1-3.

18. Wong, P. T. W., and Baker, R. 1984. Suppression of wheat take-all and Ophiobolus patch by fluorescent pseudomonads from a Fusariumsuppressive soil. Soil Biol. Biochem. 16:397-403. 